\title{
EMPOWERMENT OF COASTAL COMMUNITY THROUGH VILLAGE POTENTIAL
}

\author{
Siti Hajar \\ Faculty of Social and Political \\ Sciences \\ UMSU \\ Medan, Indonesia \\ sitihajar4416@gmail.com
}

\author{
Irwan Syari Tanjung \\ Faculty of Social and Political \\ Sciences \\ UMSU \\ Medan, Indonesia
}

\author{
Elvita Yenni \\ Faculty of Social and Political \\ Sciences \\ UMSU \\ Medan, Indonesia
}

\begin{abstract}
Empowerment of coastal villagers as one of the government programs to support the distribution of development through the development of village potential both human and natural resources. Development of village potency especially in coastal village aim to improve village progress so that able to compete according to national development goal that is to realize prosperous society, independent and competitive. The village community empowerment program in an effort to improve the ability of people in all fields, in particular creating creativity to produce an independent and prosperous society. The ability of these communities must also be supported by the mindset of the community that can support any activities undertaken in the Pesisir Village, especially the Paluh Manan Village. Community empowerment is also a concrete manifestation to increase community participation in every development program because the key to the success of development can not be separated from the direct involvement of the community in the implementation of development. The empowerment of coastal communities through the potential of villages is also expected to be a tangible manifestation in implementing village legislation in promoting the village. Therefore, prior to developing the potential of the village, this community empowerment activity is carried out by grouping the potential of the village that can be developed, then forming a team or group at the village level who served as the controller and supervisor in the implementation of coastal community empowerment through the development of village potency.
\end{abstract}

Keywords-empowerment, coastal communities and village potential

\section{INTRODUCTION}

Equity of development needs to be implemented in every area of life, because it is related to the development and progress of a particular area of the village. Development of village progress is also concerned with creating a society that is able to compete and face the challenges of globalization.

The main issue that needs the empowerment of rural community to realize prosperous society as expected in the implementation of act No. 6 Year 2014 About the Village, is still lack of education level of society, lack of clean environment management so often face health problem, low of mindset of society for village management. This is the main reason for the need for a participatory approach in realizing a prosperous society, especially coastal areas

Implementation of community empowerment aims to improve community welfare and creativity of the community empowered through the potential and excellence of the village and its community. The potential development of rural communities is one solution that can be applied in realizing the progress of the village.

Community empowerment is a continuous program that deals with developing conditions and situations of potentially powerful people's development. This community empowerment program is also one of the important programs in the distribution of development as a concrete manifestation of the reality and demands of society.

\section{REVIEW OF LITERATURE}

\section{A. Empowerment}

Empowerment can be interpreted as the acquisition of strength and access to resources to earn a living. Arsiyah, DKK (2009) states that the concept of empowerment is a new paradigm in community development involving the community in development activities both in planning, implementation and evaluation. Ife in Zubaedi (2014) identifies several types of strengths people have and can be used to empower them:

1) The power of personal choice. Empowerment efforts are done by giving people the opportunity to make personal choices or opportunities for a better life.

2) Strength in determining its own needs. Empowerment is done by assisting them to formulate their own needs.

3) Power in freedom of expression. Community empowerment is done by developing their capacity for free expression in the form of public culture.

4) Institutional strength. Empowerment is done by improving the accessibility of the community to the institutions of education, health, family, religious, social welfare system, government structure, media and so forth 
5) The power of economic resources. Empowerment is done by increasing accessibility and control over economic activity.

6) Strength in reproductive freedom. Empowerment is done by giving freedom to the community in determining the process of reproduction.

Thus, the empowerment of the village community is the development undertaken for the community by increasing knowledge, skills to improve the ability to determine its own future and participate in influencing its own life.

\section{B. Coastal Communities}

The term coastal area, is an area directly adjacent to the edge of the beach or sea. Amanah (2010), states that coastal communities have a distinctive life, faced directly in harsh ecosystem conditions, and the source of life that relies on the utilization of coastal and marine resources. Theoretically coastal communities are defined as people who live and conduct socio-economic activities related to ocean resources so as to have a high degree of dependence on seafood. While Mubyarto (2002) coastal communities, especially fishermen in general, are categorized as poorer than farmer families or craftsmen.

The physical condition of the settlements and the livelihoods of the coastal villagers is divided into three categories: permanent home (qualified health), semipermanent house (enough to meet health requirements), nonpermanent house (less or no health requirements). However, in general the condition of coastal community settlements more to non-permanent homes. There are several characteristics of coastal communities proposed by Wignyosoebroto (2009), namely:

1) Greatly influenced by the type of activity

2) Greatly influenced by environmental factors, seasons and markets

3) Structure of society that is still simple and not entered by outsiders. This is because both culture, living order and community activities are relatively homogeneous and each individual feels the same interests and responsibilities in implementing and overseeing mutually agreed laws.

4) Most coastal communities work as fishermen.

\section{Village Potential}

The development and progress of the village depends on the village's potential. Some of the potentials of the village include the various natural (physical) and human (nonphysical) resources owned by a village and have benefits for the survival of the village. Maksudin (2001), which are included in the village potential are:

Physical potential, including:

1) Land, including minerals and minerals, sources of crops that are a source of livelihood, food and shelter.
2) Water, including water resources, conditions and water system for irrigation, agriculture and daily living needs.

3) Climate, its role is very important for agrarian villages.

4) Livestock, as a source of energy, food and income.

5) Man, as a potential man power (power man) both land processors and producers in the field of agriculture, as well as industrial workers in the City.

Non-physical potential, including:

1) Villagers living based on mutual cooperation and can be a force of production and building power on the basis of cooperation and mutual understanding.

2) Social institutions, education and social organizations that can provide social assistance and guidance to the community.

3) Apparatus or village opportunity, to maintain order and security for the smoothness of village government only.

\section{EXECUTION METHOD}

This research is conducted with survey research, which aims to know the potential and advantages possessed by the village of Paluh Manan. Survey data obtained will be grouped based on the grouping of potential villages so that it can be known the advantages of each potential owned by the village of Paluh Manan.

\section{RESUlTS}

The diversity of village potentials that can be developed in accordance with community choices and capabilities. The most potential villages in the village of Paluh Manan are in the field of fishery / aquaculture and agriculture. This is in accordance with the level of community livelihood of fishermen and farming. This livelihood is the dominant work done by the village community.

The potential of the village owned by Paluh Manan Village, in its development process to support the community empowerment program has constrained the low level of education and knowledge of the community about the management of village potency. The number of natural conditions that have to get special attention related to empowerment. One example put forward by the fishing community leaders is that they cannot cultivate waste from their aquaculture.

The preservation and management of resources that ultimately become the potential of a region is not as easy as turning the palms so it takes the involvement of all parties. One of the parties expected to be directly involved in conservation and management activities with community empowerment programs is community leaders. The involvement of community leaders in Paluh Manan Village is one of the keys to the success of the development program, especially the empowerment of the community. 
Implementation of community empowerment, especially coastal village community should be extra attention. One of them is the ability and expertise that exist in the Village Government so that it can support community empowerment program. The ability of village officials in the Village Government of Paluh Manan is still relatively minimal and cannot support the activities undertaken so that needed experts who can provide solutions and knowledge in the implementation of community empowerment.

The majority of the community's livelihood of fishermen and farmers. However, some of these communities do not have the skills to support their work. The fishermen in this village of Paluh Manan $\pm 65 \%$ have no identity and cannot read. So also with the farmers, so it becomes a fundamental problem to develop the creativity and progress of this village.

In agriculture too, people working as farmers cannot cultivate resources from agricultural land because of the low ability to produce their crop productivity. Fish, shrimp and crab farming are also categorized as farmers. In terms of cultivating production output is also relatively low so it takes permanent control and control so that it can produce productive results such as seeds and food.

Farmers of fishponds and fishermen are far different characteristics in cultivating and cultivating the potential that exists. Fishermen are open access who seek results by moving to get maximum results and the risk of fishing jobs is also quite high. Fishermen have a hard character, firm and open.

Community work in Paluh Manan Village, everyone can be a fisherman and farmer. Their work depends on natural conditions and supporting ecosystems. Firth (in Zubaedi: 2014) says the fisherman community has a resemblance to the peasant society, namely that the nature of its business is small with simple equipment and market organization; exploits that are often related to cooperative issues; largely relies on subsistence production; and has a diversity in the level and behavior of its economy.

\section{CONCLUSION}

The development of village potentials requires the participation of various parties in the management and preservation. Village potential is needed to support development programs, especially community empowerment. The each village must be able to classify the potential of the village owned so that it can be the advantage of the village for implementation of community empowerment, especially coastal areas. The progress of coastal areas depends on the potential of both natural and human resources, it is necessary community empowerment program to develop the potential of the village so as to achieve the goal of improving the welfare of community.

\section{References}

[1] Aminah, Siti. Gondang Bakau dan Orang Pesisir. Ashoka Indonesia: Bandung. 2000

[2] Asiyah., Ribawanto, Heru dan Sumartono. Pemberdayaan Masyarakat Dalam Pembangunan Ekonomi Desa (Studi Kasus Pemberdayaan Masyarakat Industri Kecil Krupuk Ikan di Desa Kedungrejo, Kecamatan Jabon, Kabupaten Sidoarjo), Jurnal WACANA Volume 12 Nomor 2 April Tahun 2009 ISSN 1411 - 0199, Universitas Brawijaya: Malang.

[3] Mubyarto. Penanggulangan Kemiskinan di Jawa Tengah Dalam Era Otonomi Daerah. Jurnal Ekonomi Rakyat, Artikel Tahun I Nomor 9 November 2002. www.ekonomirakyat.org.

[4] Maksudin. Strategi Pengembangan Potensi dan Program Desa Binaan/Mitra Kerja IAIN Sunan Kalijaga Yogyakarta. Aplikasia, Jurnal Aplikasi Ilmu-ilmu Agama, Volume 11 No.2 Desember 2001

[5] Undang-undang Nomor 6 Tahun 2014 Tentang Desa

[6] Wignyotosoebroto, Soetandyo. Dakwah Pemberdayaan Masyarakat: Paradigma Aksi Metodologi. Pustaka Pesantren: Yogyakarta. 2009

[7] Zubaedi. Pengembangan Masyarakat (Wacana dan Praktik). Kencana: Jakarta. 2014 